\title{
China plans clean sweep on dust storms
}

\section{David Cyranoski}

Chinese researchers at home and abroad are rallying allies around the world to confront a gritty subject that has growing implications for public health and the environment: dust.

The dust storms, which arise in China's northwestern plains and normally hit Beijing each spring, have become increasingly intense over the past few years. And the country's leaders are concerned not just for the health of the capital city's 13 million residents, but also about the implications for the government's pledge to stage a 'green' Olympic Games there in 2008.

So China is pouring substantial funds into research on the origins and impact of the storms - equivalent to tens of millions of US dollars over the next few years, according to one leading researcher's estimate with agencies and institutions scrambling for a slice of the action. "Dust-storm research is a golden baby in China - everyone wants to hold it," says Zhanqing Li, who uses satellite imaging to study the storms at the University of Maryland in College Park.

$\mathrm{Li}$ even predicts that dust-storm research could become the first field of modern science in which China assumes clear global leadership. Last November, the Chinese Academy of Sciences gathered scientists from nine countries - including France, Japan, Korea, Russia and the United States in Beijing to discuss the integration of different countries' research on dust storms. The 62 delegates signed up to the Beijing Declaration on an International Dust Storm Program, under which the Chinese Academy of Sciences will "formulate the framework for the development and implementation of an integrated scientific research program".

A Chinese-US workshop on dust storms and their effects on human health also took place in November at North Carolina State University in Raleigh. It produced an agreement on how to study dust storms, from their origins right through to their environmental and health impacts, says the meeting's organizer, Lian Xie, a climate modeller at North Carolina State. The workshop was initiated by the North Carolina chapter of the US-based Chinese Association for Science and Technology and the China Meteorological Administration, and drew sponsorship from five US government agencies. China regards collaboration with the United States as vital - particularly because of the latter's immense satellite-imaging capability.

Researchers from the two countries discussed common strategies for approaching all aspects of the dust problem. The North Carolina meeting highlighted the keen involvement of US-based, Chinese-born researchers in the subject. "Many of us lived through dust storms in China," Xie explains.

Dust storms, as they pass between continents, have been found to contain a cocktail of natural and industrial particulates and aerosols. "You get an incredible mix of all kinds of aerosols that you don't see anywhere else," says Joseph Prospero, an aerosol chemist at the University of Miami.

In China, meanwhile, many believe that desertification - which is partly the result of overgrazing and poor land-use policy — is a principal cause of the storms' increasing intensity. China has already relocated farmers in some areas in an attempt to address the

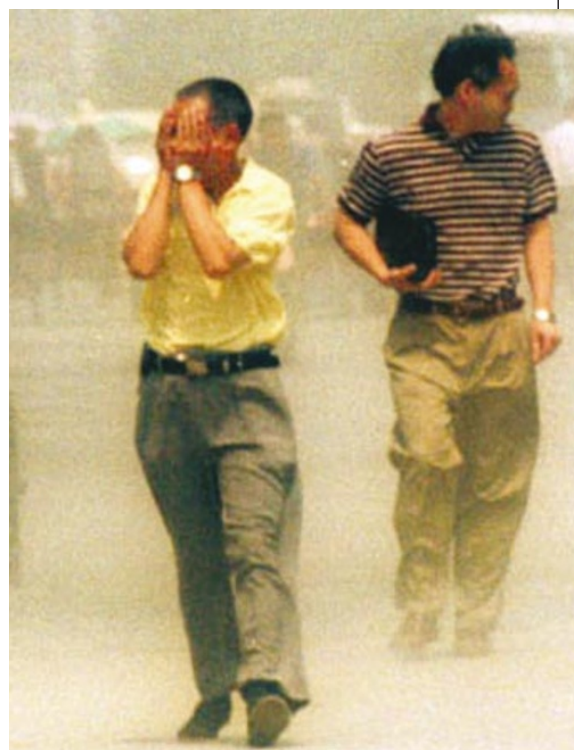

Choked: the health effects of Beijing's annual dust storms remain a clouded issue.

problem. But Prospero thinks it is more likely that long-term climate trends are to blame.

For some researchers, a question mark remains over governments' willingness to confront the effects of dust storms on human health. According to literature distributed at the North Carolina meeting, "noxious aerosols kill 1 in 14 people, and pneumonia, often from breathing dirty air, is the leading cause of death among children in China". Eugene Shinn, a geologist with the US Geological Survey in St Petersburg, Florida, says: "The problem keeps getting swept under the rug."

\section{Indian prime minister pledges to revamp science}

\section{K. S. Jayaraman, Bangalore}

India is to mount a determined effort to attract its scientists home from abroad and to strip its scientific agencies of excessive bureaucracy, under a science policy document released last week.

The Science and Technology Policy 2003 - which has taken years to produce - was unveiled on 3 January by Prime Minister Atal Bihari Vajpayee at the Indian Science Congress in Bangalore. He appealed to India's "scientific diaspora" to return to the country to help him realize his "vision of making India a developed nation".

"We have to ensure that our scientific institutions do not become afflicted with the culture of our government agencies," Vajpayee said. "Seniority should not displace merit; talent should not be suppressed."
Vajpayee also pledged that the government would make the required budgetary commitment to increase Indian spending on research and development by government and industry - to at least $2 \%$ of the gross domestic product by 2007 . Valangiman Ramamurthi, the science and technology secretary, claims that this will not be difficult, as spending has already risen from $0.8 \%$ in 2000 to $1.08 \%$ in 2002 .

Ramamurthi adds that "the mechanisms will be in place very soon" to attract home scientists who have left India. He says that the new policy will be rapidly implemented and will give universities and research institutions greater autonomy.

Government officials say that under the policy, science-based ministries will be run by scientists and engineers, and other ministries will appoint scientific advisory committees. They also say that selected universities and scientific institutions will get money to strengthen their infrastructure. But details of the funding will be left to a task force being set up to find ways of encouraging private and public investment in research.

Scientists at the conference were encouraged by the promises of greater autonomy and scientific input in decisionmaking, but were sceptical about pledges on government reform. "If the prime minister thinks de-bureaucratization is needed only in science departments, he is wrong," says J. Gowrishankar, a molecular biologist at the Centre for DNA Fingerprinting and Diagnostics in Hyderabad. "It is needed in the finance ministry, which audits the scientific institutes." 